University of Warwick institutional repository: http://go.warwick.ac.uk/wrap This paper is made available online in accordance with publisher policies. Please scroll down to view the document itself. Please refer to the repository record for this item and our policy information available from the repository home page for further information.

To see the final version of this paper please visit the publisher's website. Access to the published version may require a subscription.

Author(s): BROOME, M. \& CAREL, H.

Article Title: The Ubiquity of Moods

Year of publication: Not yet published

Link to published version: Not yet published

Publisher statement: None 


\section{The Ubiquity of Moods}

\section{Key words: phenomenology, Heidegger, moods, affects, meaning, self, philosophy}

Matthew R. Broome and Havi Carel.

Word count: 2,775

Biography:

Matthew Broome is Associate Clinical Professor of Psychiatry at the University of Warwick and Chair of the Philosophy Special Interest Group at the Royal College of Psychiatrists, UK. His research focuses on the prodromal phase of schizophrenia, the formation of delusions, and functional neuroimaging. He is currently co-editing (with Lisa Bortolotti) 'Psychiatry as Cognitive Neuroscience: Philosophical Perspectives' and 'The Maudsley Reader in Phenomenological Psychiatry' (with Robert Harland, Gareth Owen and Argyris Stringaris).

Havi Carel is Senior Lecturer in Philosophy at UWE, Bristol. She is the author of Life and Death in Freud and Heidegger (Rodopi 2006) and of Illness (Acumen, 2008) and coeditor of What Philosophy Is (Continuum 2004, with David Gamez). Her research focuses on developing a phenomenological approach to illness and on how this approach may be applied in healthcare practice and training. She also writes about depictions of illness and death in film and about the metaphysics of death. She is currently co-editing a collection on film and philosophy (with Greg Tuck). 
Philosophy is often caricatured as one of the most disconnected and anaemic academic enterprises. Yet in philosophers' own accounts of what drew them to the problems they have sought to address they answer, typically, in two broad, passionate, ways: wonder or anxiety. As such, philosophy, and philosophers' self-understanding of themselves and their enterprise, can serve as a way to address some of the important topics raised by Rosfort and Stanghellini. Even for philosophers, the emotional experience of moods and affects is employed in narrativity, or at least, employed when one is called to give an account of oneself. One could envisage a party conversation along these lines:

'So why did you become a philosopher?'

'Well, I wanted to go to university but wasn't interested in science or in the humanities and I've always been dreadful at languages'.

'(Laugh) But you must like something about it as you wouldn't have become a

Professor?'

'You know how it is... you drift into things. I did well as an undergraduate, my tutor suggested I should do a PhD. Found an excellent supervisor, and got a few papers published and then a teaching post...'

'You must be very committed to the subject'

'Ummm - I guess so. I thought about joining the civil service after my $\mathrm{PhD}$, but always managed to find work and the hours are much more flexible at universities!' 'Well I think it is amazing: to think and teach about such important things' 
'Do you?'

There is something slightly baffling here that may simply be part of the inherent irony and self-deprecation of some academics. The philosopher's interlocutor is asking about what philosophy means to the philosopher: why he has given his life to it. As such, she is alluding to a deeper, philosophical question that, after decades of falling out of favour, is returning to the attention of philosophers: namely, how has philosophy given your life meaning? The philosopher responds with possible irony, banality, superficiality and invokes luck rather than meaning in his narrative. He serves as Nietzsche's feared nihilist. The account offered also seems to fail to meet normative standards, and depending on how the philosopher carries it off, this gap between expectation and reality in the conversation may generate humour.

However, the greater likelihood is that the conversation will engender perplexity and disappointment in the interviewer. Rather like the characters in Evelyn Waugh's early novels, the philosopher is buffeted passively by life and luck and eschews agency or meaning. In Waugh's skilled hands this becomes tragic comedy; for the philosopher and his interlocutor we have disconnection and sadness. The crucial reason for this is that we need to use terms referring to moods, affects, meaning, emotion, when we offer an account of ourselves and when we try to understand ourselves. Otherwise something is missing and the reason a person gives for their actions either look like poor reasons or not reasons at all (Bortolotti and Broome, in press). Further, agency, rationality and selfknowledge may themselves be dependent upon reason-giving 
In invoking moods and affects in one’s narrative the practical understanding (or 'affordances') of the world one inhabits are laid open in clear view. Hence Aristotle’s account of wonder as the stimulus for philosophy. Aristotle says: 'For it is owing to their wonder that men both now begin and at first began to philosophize; they wondered originally at the obvious difficulties, then advanced little by little and stated difficulties about the greater matters’ (1984, pg. 1554). Conversely, given the experience of transcendence, of ambiguity, of finitude rather than wondrous awe, the philosopher may be motivated by anxiety (Kant’s awakening from his dogmatic slumbers, Heidegger’s battles with 'Crisis' and the flight of the gods). Either manner of accounting for one's interest seems to work normatively in the giving of reasons and in generating a narrative, and moreover, a philosophical narrative.

Our fictional dialogue and discussion above aims to reinforce the important link between narrative, reason-giving and moods and affects argued for by Rosfort and Stanghellini. To make our accounts carry weight, we need to invoke feelings, affects, moods, meaning, and purpose. However, we would seek to extend this point. In their clear taxonomy of mental states, they suggest that emotions are 'characterized by their connection to motivation and movement' (authors' italics, pg 13 of ms) and that the 'feeling dimension of emotion is what permits [us] to distinguish emotion among other cognitive functions (perception, deliberation, evaluation, judging etc.)' (pg. 14 of ms). This latter quote is somewhat grammatically opaque but the idea seems to be that 'feeling' allows us, given 
the discriminatory function Rosfort and Stanghellini attribute to it, to pick out emotional states from other non-feeling non-emotional cognitive functions.

Rosfort and Stanghellini's account is Heideggerian in several ways. Their view of the person as 'being in the world', their sophisticated understanding of attunement as constitutive to identity and action and the overall view of Dasein's (the human being) existence as care, are at the heart of their view. On Heidegger's account in Being and Time, the minimal unit of meaning is 'being in the world' (in-der-Welt-sein). This unit is not dissimilar to Damasio's. The minimal, or core, self is the embodied (if underdeveloped) self Heidegger describes as always already in a world, always already embodied. The autobiographical self is the temporal self, or the Heideggerian 'thrownprojection'.

For Heidegger, describing human existence as ‘thrown’ signals our embedded and contextual existence. A person is always thrown into a world, a habitus, an environment. There is an element of givenness to us, captured by the thought that we each have a past that is at least temporally given, fixed. We also project ourselves into a future - into projects, plans and hopes that direct our current behaviour and put it in a meaningful relation to the future. This relationship of our present to our past and our future constitutes the temporal dimension of human existence, or what Damasio calls the autobiographical self. 
The connection Rosfort and Stanghellini make to narrative towards the end of the paper is important. Viewing narrativity in relation to temporality and self-reflection provides a full picture of the person as existing in time. It also grounds the ability for therapeutic change in this particular picture of the person. We can modify our relationship to our past (through psychotherapy, religious conversion and so on) and it is this capacity for modification, for re-telling, that is significant to Rosfort and Stanghellini's emphasis on narrativity. Such a modification, in turn, will affect the way in which we view, and act towards, the future. So modifying the ways in which we understand ourselves may change both our relationship to the past and to the future.

It is important to note here that by 'understanding' (verstehen) Heidegger does not mean reflective or passive cognitive understanding. Rather, his term is loaded with active and pragmatic meaning, as well as with affective force. We understand ourselves through and in our actions, choices, forms of engagement with the world and with ourselves. We are not neutral about our life story and events; we have preferences and these preferences are expressed in the emotional response we have towards future scenarios. Compare your emotional response to being invited to eat ice-cream in the sun, to the one evoked by being thrown into a dark dungeon. One way in which we can reflect and assess future plans and projects is by tuning in to our affective responses to them.

This pragmatic and emotive view of one's self-understanding and reflexive evaluation as action-based and emotionally coloured brings together the core and autobiographical 
selves. It demonstrates the centrality of emotion to all aspects of human perception and reflection, including the cognitive and rational spheres.

The pragmatic view of 'understanding' points us to a missing aspect of Heidegger’s attempt to provide a comprehensive account of the self. This is the embodied dimension of existence he only gestures towards in isolated comments in Being and Time. In order to bring together the core and autobiographical selves, we need a unified account of human mind and body, such as the one provided by Merleau-Ponty. If our self understanding is pragmatic and grounded in concrete actions and attitudes, it must also be embodied and intimately linked to our physical capacities and actions. As Rosfort and Stanghellini write, "This view is aimed at putting person, body and world together again" (p.11). This suggested reconciliation also applies to the realm of emotions, where the authors suggest synthesising 'feeling theories' and 'cognitive theories', as emotions are rooted in both physiological reactions and psychological phenomena (pp.12-3).

However, can we think about a cognitive state that is worthy of its name, that would not be connected to motivation and movement? We should not rely on an assumption of transparency of one's mental states to oneself to delineate whether 'feeling is present' but rather keep Rosfort and Stanghellini’s helpful, almost behaviouristic, definition in mind: for us to notice anything, to take up an attitude or stance towards anything in the world or in our own consciousness, requires it to be salient and for us to care about it. As with Davidson's assault on scheme-content dualism, it seems rather incoherent to think that 
we are presented with some neutral "given", which we then subsequently appraise or conceptualize in an emotional manner.

Instead, one could learn from McDowell and reject the dualism between recognition and emotional response, without rejecting the duality. For us to notice anything, to entertain any conscious representations, requires meaning and value to be present, and for us to take up a stance towards it. Recognition implies an affective response: if we didn't care, we wouldn’t notice. (Bortolotti and Broome, 2007). Hence we would suggest that all mental states we are aware of and those that are connected with action have to be affective in some form or another. To consider the alternative, brings the idea of a dispassionate, impotent, unconnected and passive agent and with it the dangers of solipsism, Cartesianism, and what McDowell (1994) refers to as 'frictionless spinning in the void'. A mind internally coherent, but with no intentionality towards the world.

Rosfort and Stanghellini make good sense in their discussion of how moods and affects can arise from one another. Clinically, the clearest example may be that of the patient with post-traumatic stress disorder (PTSD) after a severe life-threatening trauma: this would result in a pronounced affect, and an entirely different world subsequently being inhabited due to an altered mood state. We refer to this as 'hypervigilance' but that term barely captures the profound existential changes. The world is now a place with an absence of safe havens, everyone is a potential threat: there is no rest. Putting psychopathology to one side, and considering the role affects and moods play in our own self-understanding and understanding of others, one can see how the self is 
directly constituted by the stories we tell around our affective connections to the world. Some affects are received passively to some extent: our friend dies, we get attacked, and although we can choose and have some degree of freedom as to how we interpret and appraise these events, they may lead to more long-standing changes in mood. Conversely, we can choose to generate strong affects in ourselves. Rather like Aristotle’s teaching regarding the acquisition of virtue, can we seek out affective states with a view to altering our mood and person-hood?

In contrast to the sufferer of PTSD, would the 'adrenaline-junkie' inhabit a different world of different affordances? By exposure to threatening, but positively appraised, events that lead to profound affects would there be a resultant change in mood, attunement, and mode of care towards the world? Would the dominant mode of affordance be that of a challenge, of a cause of excitement? Some of these techniques of exposing an individual to certain affective states that they may not seek out voluntarily could be viewed as one of the mechanisms utilized in psychotherapy, whether psychodynamic (transference) or cognitive-behavioural ('behavioural experiments’). Pronounced affects are manipulated in a safe environment by the therapist with the hope that longstanding changes in mood are engendered and a different world of affordances is attained.

Finally, it is the questioning nature of the person brought out by Rosfort and Stanghellini that is central to philosophy. They describe the person as 'position-taking' and 'questioning being'. And it is the evaluative stance and its reflexive mode, that are core to 
philosophy's understanding of the self and of itself. This account moves beyond Damasio’s ‘evolutionary conglomerate’ and adds a philosophical dimension to human existence itself, not only to its description. On this view, the trait that picks out human existence from other kinds of biological existence is the ability to self-reflect, to evaluate and position oneself in relation to both a physical and a social environment. And it is this evaluative dimension that Rosfort and Stanghellini see as not only cognitive but also emotive.

Heidegger's account of Dasein, the human being, as the creature whose existence (and therefore nonexistence) is an issue for it, resonates with Rosfort and Stanghellini's account. As Heidegger writes: “That Being which is an issue for this entity in its very Being, is in each case mine. Thus Dasein is never to be taken ontologically as an instance or special case of some genus of entities as things that are present-at-hand. To entities such as these, their Being is 'a matter of indifference'; or more precisely, they 'are' such that their Being can be neither a matter of indifference to them, nor the opposite.” (Heidegger, 1927/1962, pg. 67-68).

Additionally, and importantly for Rosfort and Stanghellini, Heidegger views this questioning activity as intimately linked to different kinds of moods. Some moods are more disclosive than others. Some moods, notably anxiety, reveal to us the world as a whole. Heidegger's taxonomy of Stimmungen 'moods' and Befindlichkeit 'states of mind' (or affectivity, to use Hubert Dreyfus' translation), is in agreement with Rosfort and Stanghellini's emphasis on moods as character-building and essential to moral and 
self evaluation. Moods play an important interpretative role in helping us situate ourselves in relation to a specific context or situation, in relation to the world as a whole and also in relation to ourselves. As Heidegger writes in Kant and the Problem of Metaphysics, “with every mood wherein 'something is this way or that', our Dasein becomes manifest to us” (1973/1990, p.155).

Moods are also related to our thrownness and sociality. In the same way that we 'find ourselves' in a particular world, society and context, we also 'find ourselves' in a mood. Our mood is also the background of our communication with others and our social world. And most importantly for our discussion here, moods also ground our understanding our self-interpretation and self-understanding of ourselves as being in a particular world (Carel 2006).

Moods are not epiphenomenal to our uncovering of the world; they are rather constitutive of this uncovering. They reveal the world, disclose our thrownness into it and enable us to respond to it. Moods are also the core of our openness to the world. They show us the world as something that can affect us. Different moods are different ways to realise our relationship to the world. In this sense they are not subjective or internal. Rather, they reflect a relation between us and our world (ibid.).

It is ultimately the significant role moods play as reflexive evaluators, that ties together the sophisticated cognitive functions of the autobiographical self to the visceral and prereflective core self. They also overcome the gulf between 'feeling theories' and 
'cognitive theories' of emotion. By viewing moods as contributing to the person's continuously updated reflective equilibrium we can see moods as playing a crucial role in the construction of personhood and as tying together mind and body which were artificially split by Cartersian dualist tradition. As Rosfort and Stanghellini write: “[moods] awake questions, doubts, considerations, evaluations and finally deliberations about my-being-this-person” (p.21).

So counter to the common understanding (and self-understanding) of philosophy as rational, cerebral, based on reason and argument, Rosfort and Stanghellini’s paper opens the way for us to see philosophy as requiring mood, containing a sometimes implicit emotional tonality and colouring and as being a form of attunement to the world, in both senses of the word: attunement as a form of listening or tuning in and attunement as affect, as a mood through which we are able to perceive the world at all. To return to our listless philosopher: he was not devoid of affect regarding his chosen profession, but displaying boredom or presenting himself in a restrained way. And these are not lack of mood, but a particular affectivity that discloses something about his particular vision of philosophy.

\section{References:}

Aristotle, 1984. Complete Works of Aristotle, Volume 2. Ed. Jonathan Barnes. Princeton, New Jersey: Princeton University Press. 
Bortolotti, L. and Broome, MR. 2007. If you did not care, you would not notice: recognition and estrangement in psychopathology. Philosophy, Psychiatry and Psychology 14(1) 39-42.

Bortolotti, L. and Broome, MR. in press. Delusional Beliefs and Reason Giving. Philosophical Psychology

Carel, H. 2006. Life and Death in Freud and Heidegger. New-York \& Amsterdam: Rodopi.

Heidegger, M. 1927/1962. Being and Time. Trans. J. Macquarrie \& E. Robinson. Oxford: Basil Blackwell.

Heidegger, M. 1973/1990. Kant and the Problem of Metaphysics. Trans. R. Taft. Bloomington: Indiana University Press.

McDowell, J. 1994. Mind and World. Cambridge MA: Harvard University Press. 